\title{
Analysis of Demotivating Factors Affecting Students' Willingness to Speak English
}

\author{
Erlinda Sonya Pale \\ University of Timor \\ Erlinda_pale@yahoo.com \\ Maria Wihelmina Wisrance \\ University of Timor \\ anchewelan@gmail.com
}

\begin{abstract}
The hesitation to speak English in the class was the crucial problem that occurred in semester seven students of the English Department of Timor University. This study figured out the discouraging points that influence the students' eagerness to speak English in the class, the most dispiriting factors, and the attempt that they executed to overcome their problem. The subject of the study was 30 semester seven students of the English Department of Timor University. The qualitative method was employed to analyze the data in this study. Interview and questionnaire were applied as the instruments to obtain the data. The result of the study pinpointed that there were internal and external factors that affect discouraging students in the classroom. The finding also revealed that the most demotivating factors which affected the students' willingness to communicate in English were motivation and confidence. The students also performed a few things to overcome their problems. The conclusion required the students to prompt themselves and be prompted by other people to pursue a good interaction in English.
\end{abstract}

Keywords: demotivating, students, willingness 


\section{INTRODUCTION}

English has been widely used around the world as one of the International languages. The presence of English can be seen by the users of it all over the world.Some countries use English as the first language, a foreign language, and some others use it as the second language. Countries such as the USA, Canada, Britain, Ireland, Australia, New Zealand, South Africa, and several Caribbean countries speak English as their first language while Singapore, India and Malawi speak English as their second language in which English becomes part of their chief institutions. China, Japan, Greece, Poland, Indonesia, etc admit English as their foreign language where they use it as an international language (Crystal, 2003).

The use of English in Indonesia has been started in the past since the colonialization of England Most of the library books used in Indonesia are written using the English language. Consequently, to comprehend the books' content, Indonesian people have to understand English. Moreover, the students from secondary to a high level have been learning English as the foreign language started from 1945, the starting point of the independence (Alisyabana, 1990: 320; Nababan, 1984 in Bire, 2016). The use of English in Indonesia is quite crucial since it is the means of communication in trading, transport, foreign affairs, science, and technology (Bire: 2016).

Nowadays, English is considered a compulsory subject for the students of elementary to university. The teaching and learning of English are started from the very simple material in the level of elementary. When it comes to students of the university, especially those who pick it as their major of study, the content is getting more complex. English language skills such as literal listening, interpretive and critical listening, speaking for everyday communication, speaking for group activities, speaking for a formal setting, etc are instances of mandatory subjects in the English department (Timor University, 2016]. Those subjects are due to assist the students to implement English in the classroom. After all, meaningful and effective communication is the primary purpose of learning a foreign language, in this case, the English language (Mahdi, 2014]. Moreover, oral communication skills are concerned to be the primary and significant skills in the learning of a foreign language. Communication skill is an applicable item or something that has to be practiced on a constant basis, therefore using it properly and successfully necessitates ongoing practice (Apriani \& Anshori, 2019). 
Educators keep on looking for appropriate approaches to assist foreign or second language learners of English (EFL/ESL) to enhance their skill of speaking. The skill is firmly linked with the eagerness to interact with one another[Aomr, Seng, \&Kapol, 2020].

Willingness to communicate (henceforward called WTC) was conducted in L1 for the first time by Mccroskey and Baer (1985, in Bukhari, Cheng \& Khan, 2015). They include communication competence, communication apprehension, self-esteem, and diversity of culture as original places of WTC. Those four elements support someone's WTC WTC is the behavior of someone to communicate actively in certain conditions and apply a variety of topics, tasks, and interlocutors (Kang in Tuyen \& Loan, 2019] Willingness to communicate is related to factors had by learners themselves and the place where they interact (Tuyen and Loan, 2019). Mcintyre (1998, in Lauherta, 2014] considers the willingness to communicate in a second language is much harder than in a first language since communicative competence is obvious in L2 in a greater range. Learning a new language, L2, is not an easy task to do. Several new rules need to be taken into consideration to produce a meaningful interaction. Thus, the students' engagement depends much on the role of WTC which is quite crucial (Vongsila and Reinders, 2016).

Concerning the difficulties encountered by second language learners, a variety of factors are considered to affect the learners Two types of variables have been identified by researchers to affect the willingness of students to communicate. Those factors are mental variables mentioned as self-confidence of the second language learners, recognized conversational proficiency, learning nervousness of second language learners, motivation of learning, and psyche; and circumstantial variables mentioned as roles or attitudes of teachers, kinds of task, materials, the atmosphere of the classroom, and speakers (Tuyen and Loan, 2019). Those factors are believed to have influenced the students' desire to communicate.

Based on the researchers' experiences when they teach English to the seventh-semester students of the English Department of Timor University, the students rarely speak English in the classroom. When the instructions were given in English the students seemed to less active than when the instructions were given in the Indonesian language. Therefore, the present study is organized to seek answers to the next questions: (1) What are the demotivating factors which affect students' willingness in speaking English in the department of English at Timor 
University, (2) What are the most demotivating factors that occur? and (3) How do the students deal with those demotivating factors? By carrying out this study, it is due to reveal the reasons why the students feel hesitant to speak English and find out any efforts they do to deal with the problem.

\section{THEORETICAL FRAMEWORK Psychological variables}

Psychological conditions are co-constructed by interacting contextual variables including interlocutors, the topic, and the context of the conversation (Kang in Kruk, 2018). When learners would like to communicate, they will consider the person they are talking to, whether the person will make them comfortable or not to convey their ideas. A topic that is too difficult also could cease learners to start talking The learners would probably avoid certain topics to discuss as a result of being unfamiliar with the topic Moreover, the place and condition of the conversation could affect someone's willingness to communicate. Crowded people could hinder learners to start communicating as a lot of things are considered before starting to communicate In addition, whenever learners feel uncomfortable with the condition around them, their WTC will reduceHence, it seems quite necessary to conduct a positive ambiance in the classroom to support the learners' psychological to get involved in the communication process.

L2 Self-Confidence: The fact that self-c onfidence of $\mathrm{L} 2$ varies in terms of the effect on WTC of students has been asserted by researchers. A large number of students who learn L2 indicated low participation in the communication process as the result of low self confidence (Mcintyre et al, 2003 in Vongsila \& Reinders, 2016).

Perceived Communication Competence: Related to perceived communication competence, Macintyre et al (1998 in Tuyen and Loan, 2019) affirmed that the perceived communicative competence of the students is measured as the acumen regarding the capability to communicate using L2 with others. L2 learners who consider themselves as poor communicators tend to have less willingness to communicate or vice versa. Hence, it is clear that the eagerness of learners to convey ideas or feelings is closely connected to their discerned communicative ability. The purpose of training speaking should be to improve communication efficiency. The attainment of the goal necessitates 
collaboration on the part of both the instructor and the students, in which the teacher not only understands what to do in terms of teaching speaking, but also motivates and even raises awareness among the students about the importance of the topic (Gusmuliana et al, 2020).

L2 Learning Anxiety: Related to learning anxiety of L2. Some factors are considered, mentioned as character anxiety, juncture anxiety, and situation particular anxiety (Macintyre \& Gardner, 1991 in Tuyen \& Loan, 2019) Anxiety encountered by learners in L2 classes occurs because of speaking activities. The anxiety of learners hinders them to fully maximize their oral skills The study of Baker and Macintyre (2000, in Tuyen \& Loan, 2019) uncovers several major factors which determine students' reported WTC level, included anxiety of language practice, favorable or unfavorable former communication training.

Students" motivation Obviously, learners with high motivation will have a willingness to communicate in English. Motivation is one of the characteristics that influence people's ability to learn a language efficiently. In other words, if the motivation is bigger, the consequence of learning will be larger. Motivation has been identified as a series of events that result in the action of ideas, feelings, and emotions. Motivation is the most important component in determining the speed and productivity of language analysis (Gusmuliana et al, 2020). The motivation could then support them to be bold to start communicating. As put forward by Songsiri (2007, in Juhana, 2012), one point that determined students' success in speaking is motivation Students with high motivation to speak would have more progress than those who do not. Such progress then supports their improvement in learning. In this sense, motivation has a role as an essential key to determine learners' readiness to express their ideas orally (Juhana, 2012). Furthermore, Zua (2008, In Juhana, 2012) affirmed that any kind of motivation is considered as inner energy which can improve learners' interest. $0 n$ the other hand, students who possess low motivation in learning a language would not start talking as they lack inside support. Thus, teachers of English need to create such a positive atmosphere that can encourage students to build up their motivation for the success of learning to communicate. When the students' motivation is encouraged, their WTC also will be increased.

In line with the factors affecting students' willingness to communicate, one requirement for the students in studying a language is to be willing to communicate. Consequently, the students' oral involvement in the classroom context is required[Bernales, 2016). Furthermore, the 
real implementation of studying a language is to practice it for the sake of communication, not merely the memorization of a bunch of vocabulary and grammar. As pointed out by Vongsila and Reinders (2016) that the main purpose of several English programs is to improve the learners' spoken construction of the language.

On the other hand, the English department students of Timor university do not use English mostly in the teaching and learning process. They prefer to use Bahasa Indonesia, their first language This is an issue that needs to be overcome. As students of the English department, using English should be a must. After all, they will become prospective English teachers after graduating from the department, who will have to teach their students English, including teaching them how to speak in English.

Several types of research have been carried out concerning the students' problem in speaking English. Lahuerta (2013) examines the connection between the variables which are believed to affect Spanish undergraduates' eagerness to communicate in EnglishThe participants of this study were students majoring in several degrees at Oviedo University.The result of the analysis using regression indicated that there was a strong connection between motivation and willingness to speak English in the classroom. Besides, it also indicated a significant positive relationship between self-perceived communication competence and willingness to communicate, and a significant negative relationship between anxiety and self-perceived communication competence. Thus, we can see a link between self-perceived communication competence and L2 competence. This study is getting more complete with the finding on a gender difference in the effect of self-perceived competence on actual L2 competence. However, the study was carried out in a European country, therefore the finding could not be generalized to other places in a different country, such as Indonesia. The next study conducted by Wijaya and Rizkina (2015] aimed at:(1] examining the level of Indonesian students in their willingness to communicate (WTC) in the English language, and (2) revealing the particular factors which affect students' WTC in English.The result uncovers that $72,1 \%$ of 136 students possess a low willingness to convey ideas or feelings in the English language Besides, it was discovered that type of task, class size, language anxiety, teachers' and students' rapport were mostly had an impact on WTC of the students. The finding of this study was mostly related to external factors which hinder learners to communicate in English. Thus, the 
present study would seek both internal and external factors to uncover the most demotivating factors influencing learners' eagerness to speak English in the classroom. Furthermore, the study of Khoyar, RafikGalea \& Hwee Kho (2018) scrutinizes the willingness to communicate (WTC) in English among ESL undergraduates in Malaysia. A hypothesized model that integrates WTC in English, motivation, selfefficacy, mindset, and performance was tested using structural equation modeling (SEM). The results show that the personality of learners is directly affecting motivation and WTC in English. Further, the results also demonstrate that both motivation and academic achievement influences WTC in English indirectly through self-efficacy. The final model correlates well with the data, thereby indicating the potential of academic achievement that can contribute to ESL communication. On the other hand, the finding of this study was conducted in Malaysia, thus it is dealing with the learners who speak English as their second language, not a foreign language. Therefore, the current study would investigate the learners who speak English as a foreign language. Maryansyah (2019] conducted a study to investigate factors affecting willingness to communicate in English in social media. This research employed a descriptive method. Particularly, the research described factors influencing students' willingness to communicate in English in social media at the English study program in the fourth semester of the Muhamadiyah University of Bengkulu in the academic year 2018. The results revealed that there were five factors affecting willingness to communicate in English in social media. They were self-confidence, personality, motivation, attitude, and apprehension. Motivation became the greatest factor influencing students' eagerness to speak English in the classroom. Some reasons why students are eager to communicate through social media were also provided to enrich this study. On the contrary, this study implemented social media as the place to obtain the data, while the current study would use classroom context for collecting the data. Lastly, the study of Tuyen and Loan (2019) was carried out at a private university in Ho ChiMinh City-Vietnam (henceforth called PU). The study aims at exploring the students' WTC in EFL speaking classes; seek factors that influence their WTC, and propose strategies to motivate them to communicate in speaking classes. The findings of the study affirmed that a large number of PU students had a low level of WTC in English. Moreover, it was disclosed that students' WTC was affected by both individuals as well as situational factors. Finally, several vital strategies 
were put forward to help enhance the students' WTC. Based on the findings of this study, some pedagogical implications for stakeholders were provided. The different finding was uncovered by Pakpahan et al (2017) which found out several primary factors to have influences on students' unwillingness to speak English, mentioned as linguistic, psycholinguistic, socio, cultural and institutional factors. Those factors were different from previous researchers. Furthermore, their finding also put socio-cultural and institutional factors as the most factors which affect the students' unwillingness to speak English in the classroom context A study by Siagian and Udam (2017) focused on one of the factors which contribute to the unwillingness of the students to speak English, which is anxiety. $A$ couple of factors which cause the students to hesitate to speak English, namely lack of familiarity of the task, fear of making mistakes, low motivation, incomprehensible inputs, lack of confidence and then low English proficiency were the finding of this study. They also provide the strategies of the students to deal with their unwillingness to speak, they comprised assistance from peers, training time, enjoyment, great expectations, and acceptance. Riasati and Rahimi (2018) conducted a similar study to scrutinize the eagerness to speak English from the learners of Iranian EFL in a classroom context. The result of their study exposed several factors to be recognized as bring an effect on the learners' eagerness to speak: discussion topic, interlocutor effect, insecurity, positive self-image, tutor, and the atmosphere of the schoolroom. The other study of Ningsih, Narahara \& Mulyono (2018) found out that the students' willingness to communicate was affected by their own decision to be involved in communication and the perception of the learners towards such communication.

Even though those researches have been carried out, the research in Timor University especially in the Department of English related to demotivating factors of students' willingness to use English in the classroom is still rare. Moreover, the researcher also would like to use the finding of this research for further investigations pertinent to improve the students' speaking skills.

\section{RESEARCH METHODOLOGY}

The current study applied qualitative research as a tool to analyze the data, which were collected by referring to questionnaires completed by the subject of the study. In addition, interviews with some 
subjects were conducted to enrich the data. The interview helps us explain, better understand, and explore the research subject's opinions, behavior, experiences, phenomenon, etc. Interview questions are usually open-ended questions so that in-depth information will be collected. Interviews are particularly useful for getting the story behind a participant's experiences. The interviewer can pursue in-depth information around the topic. Interviews may be useful as follow-up to certain respondents to questionnaires (McNamara, 1999). The issue presented here is factors that affect the hesitation of the students to speak English in the context of the schoolroom.

Pertinent to the research methodology, the students were given a sheet of questionnaire to be answered. The questionnaire consisted of six questions dealing with aspects affecting the willingness of the students to communicate in English and their efforts to overcome their problem. For the sake of enriching the data, interviews with five students were conducted. The purpose of doing the interview was to figure out more factors that were considered as obstacles in speaking English by the students. Moreover, the students' endeavors to address their problems could be uncovered by conducting the interview.

The 7th-semester students of the English Department of Timor University were the main subject of this study. The main problem was triggered by the lack of using English in the learning process in the classroom. The researcher did not use all 7 th-semester students for carrying out the study, only 30 students were selected to obtain the necessary data to deal with the research.

Two types of instruments were used to gain the data, namely a questionnaire, and an interview. The questionnaires were prepared and then be distributed to the subject of the study. The questionnaire was adopted from Juhanna (2012) and comprised six questions. They were given 60 minutes to fill in the questionnaire. The first question is dealing with the student's desire to use English in the schoolroom, and the students were given five options to be chosen mentioned as very much, rather, normal, little, and not at all. The frequency of practicing English outside the classroom was put in the second question, followed by five options; always, usually, sometimes, rarely, never. The third question required the answer towards the students' opinion related to the necessity of speaking English for their future job and five options were provided: very necessary, necessary, normal, unnecessary, very unnecessary. Question 4 asked the students' feelings in the class when 
speaking English for presenting material is a must. For this question, only three options were available; motivated, anxious, and confident. The students were also asked to provide the frequency of correcting mistakes by their lecturers in question 5 , with five options as well; always, often, sometimes, rarely, and never. For the last question in the questionnaire, the researcher provided 9 factors that were considered to affect the students' performance in presenting a topic, asking questions and answering questions mentioned as preparation time, pressure to perform well, listeners' support, motivation, confidence, anxiety, typical knowledge, listening ability, and time allowed to perform. To make it clear, the questions are listed below:

1. How much do you like speaking English in class?

2. How often do you practice speaking English outside the classroom?

3. What is your opinion concerning the necessity of speaking English for your future job?

4. How do you feel in the classroom when you are required to speak English to present your material in front of the classroom, ask questions, or answer questions from your friends?

5. How often do lecturers correct your mistakes while you are performing your tasks?

6. What factors affect your speaking performance in presenting a topic, asking questions, and answering questions?

\section{FINDINGS}

The students' answers from the questionnaire were put into the frequency to answer the 3 research questions. Five criteria were used in describing the frequency of speaking English in the classroom namely, very much, rather, normal, little, and not at all. Dealing with the frequency of speaking English outside the classroom and frequency of correction by lecturers, different criteria were used, mentioned as always, usually, sometimes, rarely, and never. Concerning the necessity of speaking English for the students' future jobs, very necessary, necessary, normal, unnecessary, and very unnecessary were used. Related to the 
students' feeling when speaking English in the classroom is a must, there were only three categories used, as follows: motivated, anxious and confident.

To provide a clear description of the data, each of them was sent into the table to follow.

Table 1. Factors affecting the students willingness to speak English

\begin{tabular}{|c|c|c|c|c|c|c|c|c|c|c|c|}
\hline \multicolumn{2}{|c|}{ Q1 } & \multicolumn{2}{|c|}{ Q2 } & \multicolumn{2}{|l|}{ Q3 } & \multicolumn{2}{|c|}{ Q4 } & \multicolumn{2}{|c|}{ Q5 } & \multicolumn{2}{|c|}{ Q6 } \\
\hline Cat. & Freq & Cat. & Freq & Cat. & Freq & Cat. & Freq & Cat. & Freq. & Cat. & Freq. \\
\hline $\begin{array}{l}\text { Very } \\
\text { much }\end{array}$ & $27 \%$ & Always & $3 \%$ & $\begin{array}{l}\text { Very } \\
\text { necessary }\end{array}$ & $60 \%$ & $\begin{array}{l}\text { Motivate } \\
\mathrm{d}\end{array}$ & $60 \%$ & Always & $\begin{array}{l}36,7 \\
\%\end{array}$ & $\begin{array}{l}\text { Preparatio } \\
\text { n time }\end{array}$ & $\begin{array}{l}46,7 \\
\%\end{array}$ \\
\hline Rather & - & Usually & $10 \%$ & Necessary & $40 \%$ & Anxious & - & Usually & $\begin{array}{l}16,7 \\
\%\end{array}$ & $\begin{array}{l}\text { Pressure to } \\
\text { perform } \\
\text { well }\end{array}$ & $\begin{array}{l}46,7 \\
\%\end{array}$ \\
\hline $\begin{array}{l}\text { Norma } \\
1\end{array}$ & $57 \%$ & $\begin{array}{l}\text { Sometime } \\
\text { s }\end{array}$ & $77 \%$ & Normal & - & Confident & $40 \%$ & $\begin{array}{l}\text { Sometime } \\
\mathrm{s}\end{array}$ & $\begin{array}{l}46,7 \\
\%\end{array}$ & $\begin{array}{l}\text { Listeners' } \\
\text { support }\end{array}$ & $\begin{array}{l}63,3 \\
\%\end{array}$ \\
\hline Little & - & Rarely & $10 \%$ & $\begin{array}{l}\text { Unnecessar } \\
\text { y }\end{array}$ & - & & & Rarely & - & Motivation & $\begin{array}{l}66,7 \\
\%\end{array}$ \\
\hline $\begin{array}{l}\text { Not at } \\
\text { all }\end{array}$ & $17 \%$ & Never & - & $\begin{array}{l}\text { Very } \\
\text { unnecessary }\end{array}$ & - & & & Never & - & Confidence & $\begin{array}{l}73,3 \\
\%\end{array}$ \\
\hline & & & & & & & & & & Anxiety & $\begin{array}{l}36,7 \\
\%\end{array}$ \\
\hline & & & & & & & & & & $\begin{array}{l}\text { Typical } \\
\text { knowledge }\end{array}$ & $\begin{array}{l}56,7 \\
\%\end{array}$ \\
\hline
\end{tabular}

\section{DISCUSSION}

A different way of finding out the factors affecting the students' speaking performance in presenting a topic, asking questions, and answering questions was presented. There were nine factors provided and all the subjects of the study chose more than one factor, even some add more factors on their own. For the last part, the students came up with their endeavors to solve their problems. There was a variety of efforts they went through as stated in the following: being more confident, memorizing a lot of vocabulary, practice speaking English inside and outside the classroom, mastery of the topic, being more focused, being prepared, listen to more songs of English, watch English cinemas, being motivated, and practicing in pairs.

Based on the result of the interview, some students also added more points which are considered to bring effect on their desire to use English, mentioned as lack of vocabulary, habit, being nervous, losing concentration, interruption from the audience, and correction from lecturers.

Furthermore, there was a variety of the students' answers dealing with their endeavors to solve the problem. Those efforts were improving confidence, memorizing a lot of vocabulary, practice speaking inside and outside the classroom, mastering topics well, being more focused, being 
prepared, listening to songs of English, watching cinemas of English, being motivated, and practicing more in pairs.

Based on the data presented above, it can be noticed that some demotivating factors affect the students' willingness to use English during the learning process in English Department at Universitas Timor. Those factors were recognized as preparation time, burden of a wellperformed result, listeners' encouragement, motivation, courage, anxiety, specific knowledge, listening skill, time allowance, lack of vocabulary, habit, being nervous, losing concentration, interruption from the audience, and correction from lecturers.

The factor which most affected the willingness of the learners to speak English in a schoolroom context is confidence, which was experienced by 22 students out of 30 with the percentage $73,3 \%$ followed by motivation, which was $66,7 \%$. Clearly shown, the most factors came from the students themselves, meaning that outside factors affected them less.

In addition, the students also mentioned their efforts to solve their problems as shown by the result of the interview. Those efforts are: improving confidence, memorizing a lot of vocabulary, practice speaking inside and outside the classroom, mastering topics well, being more focused, being prepared, listening to song lyrics of English, watching cinemas of English, being motivated, and practicing more in pairs.

The result of the current study is in line with the study of Tuyen and Loan (2019) which stated that the willingness of the learners to communicate was caused by individual components like motivation and confidence. The finding of Lahuerta (2014) and Toubot et al. (2018) was also similar to the current study which pointed out that the willingness of the learners to use English was affected by motivation. These similar findings point to one important point, regardless of the places, internal components such as motivation and courage do play a significant role to have effects on the willingness of the learners to speak using English. From the interview result, we can see that the University of Timor as the only public university at the border with the country of RDTL is also facing the same problem with other places in terms of students' willingness to communicate in English. Thus, internal factors to contribute to the failure of the learners to execute the use of English should not be underestimated as proved by those researches. Those factors should be taken into consideration by all language teachers for 
the improvement of their ways of teaching. The learners need to be motivated continuously to boost their spirit and desire to communicate in English. Closely linked with that, the result of Vongsila and Reinders' study (2016) proved that teachers admitted their action as one crucial aspect to support their learners' willingness to produce oral communication in English. The finding of these two types of research also proposed some methods of teaching to be applied in the classroom.

\section{CONCLUSION}

Refer to the result of the data analysis previously stated, the researchers concluded that some components affect the willingness of the learners to communicate using English during the teaching and learning process. Those factors came from both the students themselves or known as internal factors, and from people and environment around them, known as external factors. Preparation time, lack of vocabulary, habit, being nervous, motivation, confidence, anxiety, and listening ability were internal factors. External factors included pressure to perform well, listeners' support, interruption from the audience, correction from lecturers, typical knowledge, and time allowed to perform. From those factors, it can be noted that the most factors that occurred came from the students themselves (internal factors). Moreover, the students also said that they went through some attempts to deal with their problems.

The result of the finding also indicated that students need more confidence and motivation so that they can utilize English in the classroom. Several external factors such as listeners' support, interruption from the audience, and correction from lecturers should also be considered to deal with the issue faced by the students. Furthermore, this result could be an input for next researchers to conduct a study that can improve the students' motivation and confidence to interact with each other using English, especially in the English department.

\section{SUGGESTIONS}

In line with the result of this study, the researchers suggest that a good learning atmosphere needs to be set for gaining the students' willingness to participate in the English teaching and learning process. Teachers or lecturers have to motivate the students more as external factors such as motivation from people around are considered as one of 
the aspects that influence students' eagerness to speak in English class. The main point which needed to be paid more attention to is that the students have to courage their self to be engaged more in English class.

\section{REFERENCES}

Ahmed Mahdi, D. (2014). Willingness to communicate in English: A case study of EFL students at King Khalid University. English Language Teaching, 7(7), 17-25. https://doi.org/10.5539/elt.v7n7p17

Apriani, E., Anshori, S., \& Edy, S. (2019). Eksistensi English Zone Sebagai Media Penerapan Kemampuan Berbahasa Inggris Mahasiswa Program Studi Tadris Bahasa Inggris IAIN CURUP. Cendekia: Jurnal Kependidikan Dan Kemasyarakatan, 17(2), 317-332.

Aomr, J. A. W., Seng, G. H., \& Kapol, N. (2020). Relationship between willingness to communicate in English and classroom environment among Libyan EFL learners. Universal Journal of Educational Research, 8(2), 605-610. https://doi.org/10.13189/ujer.2020.080232

Bernales, C. (2016). Towards a comprehensive concept of Willingness to Communicate: Learners' predicted and self-reported participation in the foreign language classroom. The system, 56, 1-12. https://doi.org/10.1016/j.system.2015.11.002

Bire, J. (2016). Issues in teaching English as a foreign language in Indonesia and the case of NTT. Kupang, Indonesia: Undana press.

Bukhari, S.F., Cheng X., and Khan, SA. (2015). Willingness to communicate in English as a second language: A case study of Pakistani undergraduates.Journal of education and practice,29 (6), 39-44, Retrieved from https://files.eric.ed.gov/fulltext/EJ1081256.pdf.

Creswell, J. W. (2009). Research design: Qualitative, quantitative, and mixed-method approaches. California, USA: Sage publications. Inc.

Crystal, D. (2003). English as a global language. New York, USA: Cambridge university press. 
Gusmuliana, P., \& Apriani, E. (2021, March). Improving Students Speaking Motivation by Using Role Play Technique at Institute Islamic in Indonesia. In International Conference on Educational Sciences and Teacher Profession (ICETeP 2020) (pp. 356-361). Atlantis Press.

Juhana. (2012). Psychological factors that hinder students from speaking in English class: A case study in a senior high school in south Tangerang in Banten, Indonesia. Journal of Education and Practice, 12 (3), 100-110, Retrieved from https://www.iiste.org/Journals/index.php/JEP/article/viewFil e/2887/2913

Kho-Yar, A. S., Rafik-Galea, S., \& Hwee KHO, E. A. (2018). Willingness to Communicate in English among ESL Undergraduates in Malaysia. Journal of Cognitive Sciences and Human Development, 4(1), 28-34. https://doi.org/10.33736/jcshd.1059.2018

Kruk, M. (2018). Factors influencing willingness to communicate in English in Chapter 4 Factors Influencing Willingness to Communicate in English in Second Life (Mariusz Kruk ) University of Zielona Góra Institute of Neophilology, (July).

Lahuerta, A. C. (2013). Factors affecting willingness to communicate in a Spanish university context. International Journal of English Studies, 14(2), 39-55. https://doi.org/10.6018/j.193611

Maryansyah, Y. (2019). A study on English students' willingness to communicate in English in social media. Journal of English education, 8(1), 31. https://doi.org/10.24127/pj.v8i1.1930.

McNamara, C. (1999). General Guidelines for Conducting Interviews, Authenticity Consulting, LLC, Retrieved from: http://www.managementhelp.org/evaluatn/interview.htm

Ningsih, S. K., Narahara, S., \& Mulyono, H. (2018). An exploration of factors contributing to students' unwillingness to communicate in a foreign language across Indonesian secondary schools. International Journal of Instruction, 11(4), 811-824. https://doi.org/10.12973/iji.2018.11451a

Pakpahan, M., Ikhsanudin, \& Sada Clarry. (2017). Factors Affecting Efl Students ' Unwillingness. Teacher Training and Education Faculty, Tanjungpura University, Pontianak, 6(6), 1-11. 
Riasati, M. J., \& Rahimi, F. (2018). Situational and individual factors engendering willingness to speak English in foreign language classrooms. Cogent Education, 5(1). https://doi.org/10.1080/2331186X.2018.1513313

Siagian, U. M., \& Adam, A. (2017). An Analysis of Students' Anxiety in Speaking. ANGLO-SAXON: Jurnal Ilmiah Program Studi Pendidikan Bahasa Inggris, 8(1), 03. https://doi.org/10.33373/anglo.v8i1.978

Timor University. (2016). Kurikulum universitas Timor. Kefamenanu, East Nusa Tenggara., Indonesia: Lecturers of English department.

Toubot, A. M., Hock Seng, G., \& Binti Atan Abdullah, A. (2018). Examining Levels and Factors of Speaking Anxiety among EFL Libyan English Undergraduate Students. International Journal of Applied Linguistics and English Literature, 7(5), 47. https://doi.org/10.7575/aiac.ijalel.v.7n.5p.47

Tuyen, L. V., \& Loan, T. T. T. (2019). Factors Affecting EFL Students' Willingness to Communicate in Speaking Classes at the Vietnamese Tertiary Level. International Journal of English Literature and Social Sciences, 4(2), 252-262. https://doi.org/10.22161/ijels.4.2.10

Vongsila, V., \& Reinders, H. (2016). Making Asian Learners Talk: Encouraging Willingness to Communicate. RELC Journal, 47(3), 331-347. https://doi.org/10.1177/0033688216645641

Wijaya, H.,\& Rizkina, P.A. (2015). Factors affecting students' willingness to communicate: A case study in higher education. 7th international conference on teaching English as a foreign language.

Retrieved

from https://s3.amazonaws.com/academia.edu.documents/3769749 1/Factors_Affecting_Indonesian_Students_Willingness to Comm unicate A Case Study in Higher Education.pdf?AWSAccessKeyI d=AKIAIWOWYYGZ2Y53UL3A\&Expires=1527115658\&Signatur e=kthuBkYVQNoyH0vY\%252Fup3depvz5k.

Yousef, R., Jamil, H., \& Razak, N. (2013). Willingness to communicate in English: A study of Malaysian pre-service English teachers.Canadian centre of science and education. 9(6), 205- 
Erlinda Sonya Pale\& Maria WilheminaWisrance: Analysis of Demotivating Factors Affecting Students' Willingness to Speak English?| 147

216,

Retrieved

from

https://www.researchgate.net/publication/285947103 Willing ness to Communicate_in_English_A_Study_of_Malaysian_PreService English Teachers/link/56f156ce08aed354e56fb2a1/do wnload. 
148 | ENGLISH FRANCA, Vol.5, No.1, 2021 